Neuro Images
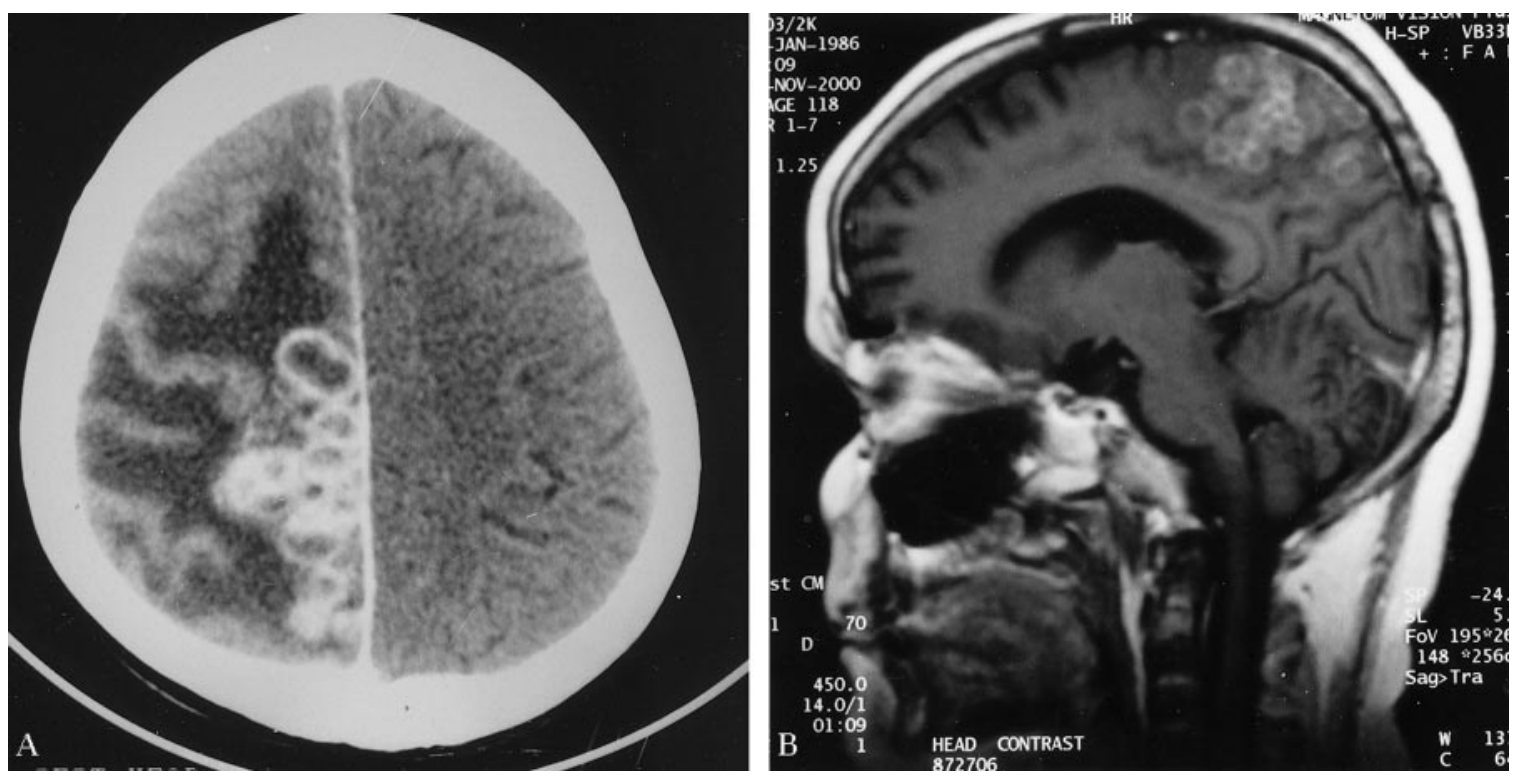

Figure. (A) Axial CT scan revealed multiple ring enhancing lesions in the right high parietal area, with perilesional edema; (B) gadolinium-enhanced MRI gave these lesions a "bunch of grapes" appearance.

\section{A "bunch of grapes" intracranial tuberculoma}

Vivek Jain, MD, Pratibha Singhi, MD, Chandigarh, India

A 12-year-old child presented with fever of 1 month and 2 episodes of left focal seizures. On examination, the child had spastic hemiparesis of the left half of the body. Chest auscultation revealed bilateral crepitations. Investigations showed a high erythrocyte sedimentation rate $(84 \mathrm{~mm} / \mathrm{h})$, positive tuberculin test $(20 \times 15 \mathrm{~mm})$, with military shadows on chest radiography. His axial CT scan revealed mul-

$\overline{\text { Address correspondence and reprint requests to Dr. Pratibha Singhi, Addi- }}$ tional Professor, Division of Pediatric Neurology, Department of Pediatrics, Advanced Pediatric Centre, PGIMER, Chandigarh, India 160012; e-mail: drsinghi@glide.net.in tiple ring enhancing lesions in the right high parietal area (figure, A) with perilesional edema; gadolinium-enhanced MRI gave these lesions a "bunch of grapes" appearance (figure, B). Owing to progressive neurologic deterioration, excisional brain biopsy showed epithelioid cell granuloma, caseous necrosis, and positive staining for acid-fast bacilli. The CT images of tuberculoma may vary from small, discrete rings to a conglomeration of multiple discs and rings. ${ }^{1}$ On contrast T1-weighted images, single or multiple conglomerate ring enhancing lesions correspond to layers of both collagenous and inflammatory cells. ${ }^{2}$

1. Bhargava S, Tandon PN. Intracranial tuberculomas: a CT study. Br J Radiol 1980;53:935-945.

2. Kim TK, Chang KH, Kim CJ, Goo JM, Kook MC, Han MH. Intracranial tuberculoma: comparison of MR with pathologic findings. AJNR Am J Neuroradiol 1995;16:1903-1908. 


\title{
Neurology
}

\author{
A "bunch of grapes" intracranial tuberculoma \\ Vivek Jain and Pratibha Singhi \\ Neurology 2002;59;1111 \\ DOI 10.1212/WNL.59.7.1111
}

\section{This information is current as of October 8, 2002}

\section{Updated Information \& Services}

References

Subspecialty Collections

Permissions \& Licensing

Reprints including high resolution figures, can be found at: http://n.neurology.org/content/59/7/1111.full

This article cites 2 articles, 1 of which you can access for free at: http://n.neurology.org/content/59/7/1111.full\#ref-list-1

This article, along with others on similar topics, appears in the following collection(s):

All Imaging

http://n.neurology.org/cgi/collection/all_imaging

All Infections

http://n.neurology.org/cgi/collection/all_infections

Bacterial infections

http://n.neurology.org/cgi/collection/bacterial_infections

CT

http://n.neurology.org/cgi/collection/ct

MRI

http://n.neurology.org/cgi/collection/mri

Information about reproducing this article in parts (figures,tables) or in its entirety can be found online at:

http://www.neurology.org/about/about_the_journal\#permissions

Information about ordering reprints can be found online:

http://n.neurology.org/subscribers/advertise

Neurology ${ }^{\circledR}$ is the official journal of the American Academy of Neurology. Published continuously since 1951, it is now a weekly with 48 issues per year. Copyright . All rights reserved. Print ISSN: 0028-3878. Online ISSN: 1526-632X.

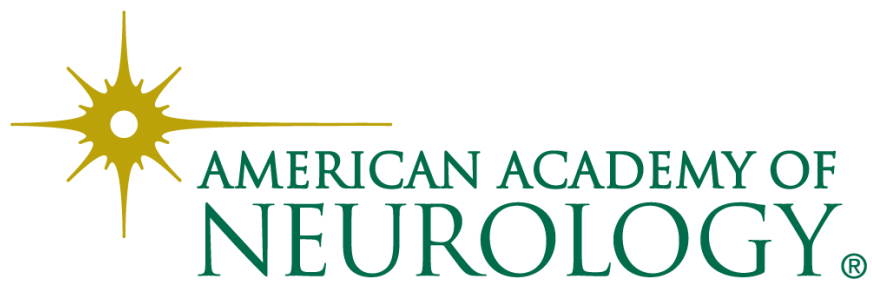

